\title{
Impact of Maintenance on the Quality of Pig Farms
}

\author{
Flores Sánchez Verónica ${ }^{1}$, Hernández Pedraza Leticia ${ }^{2}$, Vallejo Hernández Arely ${ }^{3}$, \\ Vásquez Rosas Sergio ${ }^{4}$, Juaréz Borbonio Jesús ${ }^{5}$, Chama Esteban José Luis ${ }^{6}$
}

\author{
1,2,3,4,6 Department of IMI, Universidad Tecnológica del Centro de Veracruz, Veracurz, México \\ ${ }^{5}$ Department of ER, Universidad Tecnológica del Centro de Veracruz, Veracurz, México
}

Received: 28 May 2021; Received in revised form: 25 Jun 2021; Accepted: 03 Jul 2021; Available online: 10 Jul 2021

\begin{abstract}
The 21st century clearly demonstrates the role that quality plays both in small businesses and in international companies, globalization has brought with it more demanding customers and an increasingly wide market, where the only thing that can allow companies to stay in said market is to offer consumers quality products. Juran (1993) stated "quality is simply the suitability for use satisfying the customer's needs".

The pig sector and its derivatives are an important source of employment that contributes to the development of society by guaranteeing food security and supplying the needs of the population. However, many times the quality of work in pig farms is not the best, while the importance of these farms is increasing.
\end{abstract}

The present investigation took place in the company Agroindustrias de Córdoba S.A de C.V. This company has the need to develop a quality control protocol, since the industrial maintenance that the company carries out is having a negative impact on the quality of the pigs that Agroindustrias de Córdoba S.A de C.V sells.

This research aims to assess the impact of industrial maintenance on the quality of work in the Agroindustrias de Córdoba S.A de C.V farm in order to generate a more efficient quality control protocol.

For the development of the research, methodologies such as total quality and mode analysis and failure effect were considered, to name a few.

Keywords-Quality, Pig Farms, Maintenance.

\section{INTRODUCTION}

Quality is the principle of continuous improvement; in the eighties the high competitiveness in the market Western companies discovered the great benefits that quality brings. After years of work, Japanese companies found the key to be classified as number one in the market: offering quality products and services (Tarí, J. J. 2000).

A work quality control system with solid operation is an essential factor not only in economic performance, but also in production, allowing important achievements in the market.

In Mexico, the pig industry has been of great interest, since in 2016 the Secretary of Agriculture, Livestock, Rural This article can be downloaded from here: www.ijaems.com

(C)2021 The Author(s). Published by Infogain Publication.
Development, Fisheries and Food (SAGARPA) declared that in the following years around 10 billion pesos would be invested in the sector pig, which shows clear economic growth in the country (SADER 2016).

It is important to note that the growth of the pig industry is increasing, since according to SAGARPA the annual average growth is $1.5 \%$, and there is even a commitment to achieve $3.2 \%$ in the coming years, this thanks to the beginning of exports that Mexico makes to countries like China, and even some other Asian countries (SADER 2016).

However, the quality of work in the pig industry is not the best, which consequently is generating a significant deficit

This work is licensed under a Creative Commons Attribution 4.0 License. http://creativecommons.org/licenses/by/4.0/ 
in the quality of the products that farms offer to the market, it is clear that pig farms must improve their work processes To increase the quality of the finished products they offer, this is why the present assessment of the impact of industrial maintenance on the quality of work in pig farms is used.

\section{OBJECTIVE}

Assess the impact of maintenance on the quality of the work of Agroindustrias de Córdoba S.A de C.V in order to generate a quality control protocol.

Identify what are the quality characteristics that pigs must have when they are transferred.

Evaluate the processes that are carried out in pig farms, through a Failure Mode and Effect Analysis (FMEA) of the process.

Calculate the Risk Priority Number (PRN) through the results of the FMEA.

\section{HYPOTHESIS}

A quality control protocol will allow pig farms to raise pigs in optimal conditions. In addition, through the assessment of the impact of quality, it will be known which maintenance deficits that are reflected in the quality of your pigs.

\section{JUSTIFICATION}

The state of Veracruz, Mexico has 796,223 head of pig cattle; of which 7 out of 10 are on farms, while the central zone of the state of Veracruz represents $7 \%$ of the total number of pig heads (INEGI 2014).

The quality control control protocol would be an essential tool for farms, since they would increase the quality of their pigs and thereby benefit the 55,735 head of pigs in the central area of the state of Veracruz, in addition to the protocol of quality control would increase the quality of pigs by up to $86 \%$.

Even pig farms could reduce their corrective maintenance costs by up to $37 \%$ from applying the quality protocol.

\section{PIG SECTOR ANALYSIS}

In all 21 st century companies, maintenance represents an important investment that generates great benefits, among the most significant, quality stands out.

The quality of the products allows companies to position themselves in the market.

In the world, the pork industry is an important source of economic income, only in Argentina is pork production the most efficient, since pork is among the first three most consumed meats.
Therefore, in Argentina, pig production has been prioritized in the development agenda, to such an extent that the Ministry of Agriculture, Livestock and Fisheries (MAGyP) has prepared the Master Plan for the National Pig Sector 2010-2020, whose main objective is to promote of the production, marketing and consumption of pork (Beyli, 2012).

In Mexico, the main producer of pork meat is the state of Sonora, only in 2008 it contributed $21 \%$ of the country's pork production, the main strategies of Sonoran pig farms is the constant updating of both production and processing processes maintenance (Soto, E. E, et al 2010).

On the other hand, the state of Veracruz barely reaches the sixth place in pork producers in all of Mexico, this due to the maintenance deficit in the facilities and work procedures, which as a consequence generates low-quality pork (SEDARPA 2012).

The swine unit of Agroindustrias de Córdoba SA de CV is an integrated model, since it ranges from the reproductive process to the fattening of the pigs that it markets and distributes, therefore the pig production process must be of high quality to be able to offer the best to the market, however, commonly the maintenance that is carried out is not adequate, which puts the quality of the pigs at constant risk.

\section{METHODOLOGY}

The population to be analyzed in this research is finite, since when focusing the research on a certain company such as Agroindustrias de Córdoba, the population is very limited.

It should be noted that the total population is equal to 6 individuals, who are personnel of the maintenance area in Agroindustrias de Córdoba S.A de C.V.

\section{Sample size.}

Because the population is subdivided into equitable groups in the three sites that the company has, the sample to be used is the stratified one, it should be noted that the sample size was obtained by means of the well-known statistical formula for finite population, where the assigned margin of error was equal to $0.05 \%$.

Finite statistics formula:

$$
n=\frac{Z^{2} P Q N}{(N-1) E^{2}+Z^{2} P Q}
$$

- $\mathrm{n}=$ Sample size

$\cdot \mathrm{Z}=\mathrm{Z}$ value normal curve $(0.993)$ 
- $\mathrm{P}=$ Probability of success $(0.50)$

- $\mathrm{Q}=$ Probability of failure $(0.50)$

- $\mathrm{N}=$ Population (6)

- $\mathrm{E}=$ Sample error (0.050)

Substituting values we have:

$$
\begin{gathered}
n=\frac{\left(0.993^{2}\right)(0.50)(0.50)(6)}{(6-1)\left(0.05^{2}\right)+\left(0.674^{2}\right)(0.50)(0.50)} \\
\frac{(0.986)(0.25)(6)}{(5)(0.0025)+(0.993)(0.25)} \\
\frac{(0.245)(6)}{(0.0125)+(0.248)} \\
\frac{1.45}{0.260}
\end{gathered}
$$

Therefore the recommended sample size is 5 .

The technique applied to collect the data and information was the documented analysis, since the instrument used to collect the information was a survey.

\section{ANALYSIS OF THE INFORMATION}

Which is the machinery that most frequently require corrective maintenance?

In the study company Agroindustrias de Córdoba S.A, it is considered that $20 \%$ of the time the most critical equipment is raised panels and $80 \%$ are evaporative panels.

Know the frequency of corrective maintenance interventions in the company. It is extremely relevant for the development of the quality protocol.

The study reveals that $40 \%$ suffer from a breakdown every 2 months, while $60 \%$ break down every 6 months.

Tables 1, 2 and 3 present the failure mode and effect analysis of the most critical element for pig farming.

To calculate the risk priority number, the variables are determined:

Severity: Indicates the effect of the failure on the client. It is measured on a scale of 1 to 10 , where 1 indicates a consequence with no effect.

\begin{tabular}{|c|c|c|}
\hline No. & $\begin{array}{l}\text { Potential failure } \\
\text { mode }\end{array}$ & Potential effect of failure \\
\hline 1 & $\begin{array}{l}\text { System does not } \\
\text { work }\end{array}$ & $\begin{array}{l}\text { Pigs in high temperatures, } \\
\text { the effect can be fatal }\end{array}$ \\
\hline 2 & $\begin{array}{l}\text { Water is not evenly } \\
\text { distributed } \\
\text { throughout the } \\
\text { panel }\end{array}$ & $\begin{array}{l}\text { Mineral build-up } \\
\text { The pump is exposed to a } \\
\text { short circuit } \\
\text { Unnecessary electricity } \\
\text { consumption }\end{array}$ \\
\hline 3 & $\begin{array}{l}\text { Restriction of } \\
\text { airflow to the } \\
\text { booths. }\end{array}$ & $\begin{array}{l}\text { Pigs in high temperatures } \\
\text { Loss of production (Death } \\
\text { of pigs) } \\
\text { Higher electricity } \\
\text { payments }\end{array}$ \\
\hline 4 & $\begin{array}{l}\text { Evaporated water } \\
\text { cooling cells }\end{array}$ & $\begin{array}{l}\text { Concentration of } \\
\text { bicarbonates, carbonates, } \\
\text { sulfates or hydroxides, } \\
\text { components that are } \\
\text { found at various levels in } \\
\text { many water sources. } \\
\text { The components can } \\
\text { concentrate in the } \\
\text { recirculation system, } \\
\text { resulting in an increase in } \\
\text { pH- } \\
\text { Without rinsing the tank, } \\
\text { the pH of the water can } \\
\text { become caustic, to the } \\
\text { point of destroying the } \\
\text { cellulose in the panel } \\
\text { The panel may begin to } \\
\text { look spongy like cotton, } \\
\text { losing its firmness. }\end{array}$ \\
\hline 5 & $\begin{array}{l}\text { Sediment } \\
\text { accumulation }\end{array}$ & $\begin{array}{l}\text { Sediments turn into rocks } \\
\text { that clog airways }\end{array}$ \\
\hline
\end{tabular}

Occurrence: Indicates the number of times the fault is repeated, its measurement is made on a scale from 1 to 10 .

Detection: Indicates the probability that the fault will be found before the process is completed.
Table 1 Evaporator Failure mode and effect

Table 2 Evaporator Potential cause of Failure

\begin{tabular}{lll}
\hline No. & $\begin{array}{l}\text { Potential cause of } \\
\text { failure }\end{array}$ & $\begin{array}{l}\text { Current verification } \\
\text { and / or control }\end{array}$ \\
\hline 1 & $\begin{array}{l}\text { Lack of maintenance to } \\
\text { the structure } \\
\text { Lack of maintenance to } \\
\text { the distribution system, } \\
\text { tank and pumping system }\end{array}$ \\
\hline
\end{tabular}

This article can be downloaded from here: www.ijaems.com
(C)2021 The Author(s). Published by Infogain Publication.

This work is licensed under a Creative Commons Attribution 4.0 License. http://creativecommons.org/licenses/by/4.0/ 


\begin{tabular}{lll}
\hline 2 & $\begin{array}{l}\text { Accumulation of } \\
\text { minerals in the panel }\end{array}$ & Not have \\
& Lack of maintenance \\
& Panel maintenance was \\
performed while the pad & \\
& was not wet \\
& High concentration of \\
& minerals circulating in \\
& the panel precipitating \\
the surface & \\
& Wrong water pH \\
& Accumulation of \\
& minerals in the panel \\
& Lack of filter \\
& maintenance \\
& Wrong water pH
\end{tabular}

Table 3 Risk priority number (NPR)

\begin{tabular}{lllll}
\hline No. & Severity & Occurrence & $\begin{array}{l}\text { Detectio } \\
\mathbf{n}\end{array}$ & NPR \\
1 & 10 & 3 & 2 & 60 \\
2 & 7 & 5 & 4 & 140 \\
3 & 10 & 2 & 6 & 120 \\
4 & 9 & 1 & 6 & 54 \\
5 & 7 & 8 & 9 & 504 \\
\hline
\end{tabular}

\section{RESULTS AND DISCUSSION}

\section{A) Recommended actions:}

1) Add a water softener that removes minerals from the water and even replaces them with sodium.

2) Add an acid to the water to lower the $\mathrm{pH}$ to 7 or slightly below. Will increase calcium solubility and will neutralize bicarbonates, resulting in less panel scale.

3) Have a water sanitation program that provides residual chlorine of $5 \mathrm{ppm}$ (Particles per million) in the fresh water source. It does not mean that chlorine should be put into the recirculation tank. The high concentration of chlorine will significantly reduce the life of the panel

4) Perform preventive maintenance by evaporative panel generally every month, while the filter must be serviced at least twice a month.

5) Perform preventive maintenance at least every two months to the pumping system

\section{B) Prevention and control of diseases}

Disease control and prevention can be addressed to several topics, depending on the importance given to each group of diseases:

a) Pig production is, ultimately, food production, and there are animal diseases that put public health at risk. Therefore, one of the main groups of diseases to prevent and / or control is that of zoonoses (for example, trichinellosis, cysticercosis, toxoplasmosis, brucellosis, salmonellosis and leptospirosis).

b) Other diseases that, due to their endemicity, cause significant production losses (for example, infectious pleuropneumonia).

c) In a third group, many diseases are within a legal framework because they imply a serious problem for regional animal health and international trade due to the productive losses they cause. In this case, prevention and control measures are determined or guided by national bodies.

\section{C) Product transport (pigs)}

The transfer process is extremely important and a critical point also for Agroindustrias de Córdoba, since, as noted in the survey, the employees revealed that it is very common for there to be losses when the pigs are transported.

The vehicles must be designed and built in such a way that the animals are loaded and unloaded comfortably without causing damage or injury, with aeration in accordance with the climate and the demands of the different species to be transported and whose washing and disinfection is practical and efficient.

The floor should be made of metallic or other smooth material (not presenting bare iron), to which a rigid grid mesh with non-slip properties for animals will be attached.

The waste must drain through the use of hoses of sufficient quality and thickness, with a diameter not less than 3 inches, and whose bottom opening is no more than 20 centimeters from the ground.

When dealing with trucks with more than one floor, the draining of the upper part must necessarily be implemented in the same way as in trucks with one floor.

The doors should be in such a location that they guarantee a smooth entry and exit of the animals. The guillotine doors offer easy handling and security, being advisable the double guillotine door with rear location.

In those units that have a ramp door, a checkered mesh of rigid material with non-slip property for animals and folding will be attached. 
In order to ensure proper air circulation, the side must have a sufficient number of openings on each of its sides, without projections that could harm the animals. The lower part of the sides or baseboards will be totally closed, without openings up to a minimum height of 35 centimeters.

In the case of a load of animals of different categories and / or species, they must have internal divisions of metallic material or other similar appropriate, mobile to allow an adequate closure to avoid displacement.

\section{D) Avoid:}

1) Stressful handling in the establishment in the pretransport stage. The trip should be calm and not long.

2) The waits in pens before loading and unnecessary stops should be reduced.

3) Prolonged transport, since it only generates fatigue and even gradual loss of glycogen for pigs.

4) Mobilization of animals under extreme weather conditions.

\section{REFERENCES}

[1] Amendola, L. (2003). Indicadores de confiabilidad propulsores en la gestión del mantenimiento. Departamento de Proyectos de Ingeniería Universidad Politécnica de Valencia.

[2] Beyli, ME y Campagna, D. (2012). Buenas prácticas pecuarias (BPP) para la producción y herramientas porcina familiar (No. L01 / 10335). Ministerio de Agricultura, Ganadería y Pesca, Buenos Aires (Argentina).

[3] Bobadilla Soto, E. E., Espinoza Ortega, A., \& Martínez Castañeda, F. E. (2010). Dinámica de la producción porcina en México de 1980 a 2008. Revista mexicana de ciencias pecuarias, 1(3), 251-268.

[4] Carrasco, Francisco Javier Carcer y Méndez, M. R. (2013). El mantenimiento industrial y el conocimiento tácito: Una introducción sobre su incidencia. DYNA Management. 9 de junio de 2020. http://dx.doi.org/10.6036/MN5857;

[5] Díaz, C. A., Rodríguez, M. N., Vera, V. J., Casas, G. A., \& Mogollón, J. D. (2011). Caracterización de los sistemas de producción porcina en las principales regiones porcícolas colombianas. Revista Colombiana de Ciencias Pecuarias, 24(2), 131-144.

[6] Grupo Audace. (s.f.). recuperado de: https://s763835096.websitebuilder.online/

[7] Ingeniería industrial en línea. Bryan Salazar López. Análisis de Modo y Efecto de Fallas(AMEF).10 de junio de 2021.

https://www.ingenieriaindustrialonline.com/leanmanufacturing/analisis-del- modo-y-efecto-de-fallas-amef/

[8] INEGI. (2014). Censos Económicos 2014.

[9] La importancia del mantenimiento industrial, (2017). Recuperado de http://serycoin.com/2017/05/la-importanciadel-mantenimiento-industrial/

This article can be downloaded from here: www.ijaems.com
[10] Montalbán-Loyola, Edith, Arenas-Bernal, Erika Josefina, Talavera-Ruz, Marianela, Magaña-Iglesias, Rocío Edith., (2015). Herramienta de mejora AMEF (Análisis del Modo y Efecto de la Falla Potencial) como documento vivo en un área operativa. Experiencia de aplicación en empresa proveedora para Industria Automotriz. Revista de Aplicaciones de la Ingeniería. Vol.2. (No.5). pp.230-240.

[11] Ortega Díaz, J.A., (2007). Diseño de un plan para la implementación de la gestión de mantenimiento en SAP/PM de los equipos auxiliares, de la central hidroeléctrica Antonio José de Sucre (Tesis de grado). Universidad Nacional Experimental Politécnica Antonio José de Sucre. Guayana

[12] Paramio, T. (2000). MANEJO Y PRODUCCIÓN DE PORCINO: Breve manual de aproximación a la empresa porcina para estudiantes de veterinaria. Departamento de Ciencia Animal i dels Aliments Unitat de Ciència Animal Facultat de Veterinària UAB.

[13] Olarte C., W., Botero A., M., \& Cañon A., B. (2010). Importancia del mantenimiento industrial dentro de los procesos de producción. Scientia et technica. Vol.1. (No.44). pp.354-356.

http://revistas.utp.edu.co/index.php/revistaciencia/article/vi ew/1867/1113

[14] Oña Granja, f., (2015). Diseño de un sistema de mantenimiento productivo total (TPM) en la sub-estación Pérez Guerrero de la empresa eléctrica Quito (Tesis de Pregrado). Universidad Tecnológica Equinoccial. Quito

[15] Ponce, H. R., Sosa, M. M. R. A., \& Fernández, M. A. P. (2012). Producción y Comercialización de Ganado y Carne de Bovino en el Estado de Veracruz. Comité Nacional del Sistema Producto Bovinos Carne, Veracruz, Veracruz.

[16] Sampieri, R., Fernández, C., \& Baptista, P. (2010). Metodología de la investigación (5ta. ed.). DF. DF México: Mc Graw Hill.

[17] Shkiliova, Liudmila, \& Fernández Sánchez, Manuel (2011). Sistemas de Mantenimiento Técnico y Reparaciones y su aplicación en la Agricultura. Revista Ciencias Técnicas Agropecuarias,72-77. $\quad 9 \quad$ de junio. https://www.redalyc.org/articulo.oa?id=93218850013.

[18] Tarí, J. J. (2000). Calidad total: fuente de ventaja competitiva. Universidad de Alicante. Servicio de Publicaciones. 